JEL classification: B10, J18, Q00

УДК 330.83

DOI 10.17150/2308-2488.2019.20(4).601-624

М.А. Лапыцкая

Санкт-Петербургский государственный университет, г. Санкт-Петербург, Российская Федераиия

ПРЕОБРАЗОВАНИЯ В АГРАРНОЙ СФЕРЕ КАК СПОСОБ РАЗРЕШЕНИЯ ПРОБЛЕМ КРЕСТЬЯНСКОГО МАЛОЗЕМЕЛЬЯ В РОССИИ [ПО МАТЕРИАЛАМ ИССЛЕДОВАНИЙ АГРАРНЫХ РЕФОРМ В РОССИИ ВТОРОЙ ПОЛОВИНЫ ХІХ НАЧАЛА XK ВB.]

Аннотация. В статье рассматриваются проблемы аграрного строя России, приведшие к крестьянскому малоземелью в конце XIX - начале XX вв. Исследованы особенности каждой из причин малоземелья и возможные пути решения проблем. Рассмотрены также причины, способствовавшие низкому уровню развития сельского хозяйства. Рассмотрен механизм причинно-следственной зависимости развития промышленности от состояния сельского хозяйства. Описаны особенности аренды дополнительных земельных наделов и то, в каком положении оказывались крестьяне при использовании такого механизма. Рассматривается идея национализации земли как возможного решения проблемы малоземелья крестьян. Описаны реально предпринятые правительством механизмы устранения малоземелья в России: переселение, учреждение Крестьянского банка. Выделены меры, которые действительно могли повлиять на долгосрочную перспективу развития земледелия. Для написания статьи использовались преимущественно экономические исследования аграрных реформ конца XIX - начала XX вв. Интерес к заявленной теме обусловлен постоянным обращением российской экономической мысли к организации земельного вопроса. Аграрно-эконо- 
мические исследования соединяют в себе теоретический и исторический подход, что дает возможность осмыслить прошлые хозяйственные процессы и явления с позиции современности, и наоборот, современность с позиций прошлого исторического опыта.

Ключевые слова. Малоземелье, крестьянская община, крестьянское хозяйство, дополнительные наделы, аграрные реформы, аграрный сектор.

Информация о статье. Дата поступления 18 октября 2019 г.; дата принятия к печати 31 ноября 2019 г.; дата онлайн-размещения 28 декабря 2019 г.

M.A. Lapytskaya

St. Petersburg State University, St. Petersburg, the Russian Federation

\title{
TRANSFORMATIONS IN THE AGRARIAN SECTOR AS A METHOD OF PROBLEM RESOLUTION OF THE PEASANT LAND SHORTAGES IN RUSSIAIBASED ON THE RESEARCH ON AGRARIAN REFORMS IN RUSSIA IN SECOND HALF OF XIX — BEGINIING OF THE XX GENTURIES]
}

\begin{abstract}
The article analyzes the historical peasant situation in the late XIX - early XX centuries and the problems of the agrarian system that led to the land shortage among the peasants. In addition, the research examined the roots of the land shortage problems and the possible ways to solve those. The author also investigated the reasons that contributed to the low level of agriculture development. The study reviewed the mechanism of a causal relationship between industrial development and agriculture. The article described the features of the lease of additional land allotments and how it they affected the peasants. The study considered a possibility of land nationalization as a way to address the land shortage problem. The article describes the mechanisms and steps actually taken by the government to eliminate the land shortages in Russia: resettlement
\end{abstract}


programs for the peasants and the establishment of the Peasant Bank. The study also highlighted the specific measures that really could affect the development of agrarian system in the long run. The research conducted a comprehensive analysis of the previous scientific studies of the agrarian reforms implemented in the late XIX - early XX centuries. The high interest to this topic is driven by the interest of the Russian economic theory to the land shortage issue. Agricultural and economic research used in the article utilized a theoretical and historical approach. It offers an opportunity to comprehend the past economic processes and phenomena from modern day perspective, and vice versa - to understand the modern world from the perspective of the past historical experience.

Keywords. Land shortage, peasant community, peasant farming, additional plots, agrarian reforms, agrarian sector.

Article info. Received October 18, 2019; accepted November 29, 2019; available online December 28, 2019.

Исторические этапы, в рамках которых происходят радикальные реформы и смена экономико-теоретических взглядов, определяют жизнь народа и страны на долгое время вперед. В научных сообществах развитие и функционирование крестьянских хозяйств многие годы является предметом тщательного изучения и споров. Оценивая состояние и степень разработанности темы исследования, следует отметить, что литература в этой области довольно широко представлена. Анализом агарных реформ и развитием сельскохозяйственных отношений занимались широко известные ученые и общественные деятели конца XIX - начала XX вв.: С.Н. Булгаков [1], А.В. Чаянов [2], Н.Д. Кондратьев [3], Л.В. Ходский [4], А.А. Кауфман [5], А.А. Мануйлов [6], А.В. Пешехонов [7], П.П. Маслов [8], Ф.Ф. Бар [9], Н.А. Демчинский [10], А.А. Исаев [11], П.М. Лохтин [12] и др. В статье предпринята попытка систематизации 
основных идей ученых-экономистов на основе указанных работ. Целью исследования является раскрытие особенностей агарных преобразований в борьбе с крестьянским малоземельем и выявление действенной меры, способствующей развитию сельского хозяйства, как основного показателя состояния крестьянского населения. Методологической базой исследования стали общенаучные методы: экономический анализ, идеализация, историко-логический метод; используются диалектический метод познания и междисциплинарный подход. Научная новизна работы определяется переосмыслением ранее известных фактов о причинах малоземелья и способах преобразования сельскохозяйственной отрасли, характеризующих эволюцию социально-экономических систем и аграрных институтов в исторической ретроспективе. Столь пристальное внимание в наши дни к периоду рубежа XIX-XX вв. вполне объяснимо, так как он выделяется своей противоречивостью, в это время совершается знаковый исторический поворот. Прошлый опыт экономических преобразований может существенно помочь в развитии современной экономики, учитывая ошибки прошлого, просчеты и опыт выхода России из кризисов. В начале XX в. в России наблюдался аграрный кризис, и одним из главных вопросов являлось крестьянское малоземелье. Это являлось следствием предыдущих преобразований в России и исторически сложившегося аграрного строя. Крестьянские и помещичьи хозяйства разорялись, в нищих деревнях каждые два года случался неурожай и голод. В научной литературе выделяется достаточное количество причин упадка, но основными причинами, повлекшими за собой формирование малоземелья, являлись следующие: 1) условия «Общего положения о крестьянах, вышедших из крепостной зависимости» о размере наделов и о повинностях; 2) общинное землевладение; 3) естественный прирост населения; 4) обработка земли устаревшими методами. 
После реформы 1861 г. в пользовании крестьян оказалось земли меньше, чем было прежде. К малоземельным крестьянам относились те, у кого во владении и пользовании находилось недостаточное количество земельных угодий. Самые меньшие наделы достались дарственным и помещичьим крестьянам. Принимая средний надел бывших государственных крестьян за рабочую норму крестьянской поземельной собственности, находим, что из бывших помещичьих крестьян (10 608100 чел.) только 13,9 \% получили наделы выше нормы, 43,5 \% получили наделы достаточные, и 42,6 \% получили наделы недостаточные. Таким образом, без малого половина помещичьих крестьян сразу же оказалась недостаточно обеспечена землею и стала платить огромный выкуп за такое количество земли, которое и без этого выкупа не смогло бы прокормить их. Но были те, кто освободился вообще без земли или с четвертным наделом [13, с. 149]. Если обратиться к территориальному распределению малоземельных крестьян, на основе очерка П.Н. Соковнина, который опирался на статистические материалы 1893 г. Центрального Статистического Комитета, можно сделать следующий вывод: при среднем для Европейской России наделе в 8,7 дес. пахотной земли на двор (2,6 дес. на наличную душу), средние наделы 16 губерний превышают эту норму, наделы 4 губерний подходят к ней весьма близко, в остальных же 26 губерниях наделы ниже средней нормы. К наиболее малоземельным губерниям относились: Архангельская, Подольская, Московская, Полтавская, Рязанская, Ярославская, Киевская, Тульская, Черниговская, Вологодская, Владимирская, С.-Петербургская, Костромская, Тверская, Симбирская, Орловская, Нижегородская, Пензенская, Курская, Могилевская, Калужская, Харьковская, Смоленская, Бессарабская, Казанская, Гродненская, Тамбовская, Псковская, Новгородская, Волынская [14, с. 2, 25-26]. Малоземелье привело к усугублению давних 2019. T. 20, № 4. C. 601-624 
проблем крестьянского населения. На сегодняшний день среди экономистов, историков, занимающихся этой проблемой, нет однозначного мнения о том, имело ли место малоземелье на самом деле. Если рассматривать малоземелье абсолютно, учитывая размеры страны, то по сравнению с другими странами в России не было малоземелья и быть не могло. Однако факты экономической истории, статистики показывают обратное. Определенно можно утверждать, что в деревне существовала недостаточность обеспечения трудящегося населения землей. Хотя статистические материалы XIX - начала XX вв. страдают неполнотой, тем не менее удается проследить тенденцию. Большой вклад в анализ вопроса малоземелья внес российский статистик и экономист Ю.Э. Янсон. В своих трудах он показал и доказал недостаточность количества земельного надела на душу и высокий уровень выкупных платежей [15, с. 4]. Благодаря работе Ю.Э. Янсона правительство вновь обратило внимание на возможные способы расширения крестьянского землевладения.

В поиске разрешения вопроса о недостаточности земельных наделов важно обратиться к исторической ретроспективе и специфическим особенностям причин малоземелья.

Первой причиной формирования малоземелья считаются условия Положения реформы 1861 г. После обнародования закона перед крестьянами встала нелегкая задача - самостоятельно решать свои проблемы и устраивать новую «свободную» жизнь. Основные принципы законодательного акта базировались на интересах дворян. Освобожденные крестьяне, не имевшие капитала и специальных знаний вынуждены были вновь обращаться к помещику. Также они лишились возможности пользоваться свободно непахотными угодьями (леса, луга, пастбища). При назначении крестьянских наделов, чтобы обеспечить крестьянский быт и уплату повинностей, необходимо было рассчи- 
тать размер земельного надела. Чтобы оценить удовлетворенность крестьян в размере полученного надела, необходимо его сопоставить с продовольственными потребностями земледельцев. Это сопоставление показывает, что в большинстве случаев крестьянская семья с трудом могла прокормиться, а ведь еще было необходимо исполнять повинности. При распределении повинностей был прописан такой механизм: с каждой последующей десятиной земли размер платежа уменьшался. Такой расчет ставил в тупик крестьян с минимальным наделом. Эту сторону «Положения» 19 февраля один из мировых посредников, принимавший участие в проведении в жизнь реформы 1861 г., Н.В. Всеволожский, наглядно поясняет простым расчетом. В своей весьма интересной записке, предоставленной в Особое Совещание о нуждах сельскохозяйственной промышленности и, к сожалению, оставшейся ненапечатанной, он сообщает, что в Симбирской губернии при выкупе крестьянами высшего надела помещик получал 120 р. за полный надел на душу, что составляло по различным уездам, в зависимости от величины надела, от 30 р. до 36 р. за десятину. При выкупе же крестьянами низшего надела (1/3 высшего) помещик получал, благодаря более высокой оценке первой десятины, в среднем от 45 р. до 51 р. за десятину. Таким образом помещикам было выгодно, чтобы крестьяне выкупали меньше земли [6, с. 9]. Сложившаяся ситуация повлекла за собой еще одну проблему: отказ крестьян от выкупа полного надела (в надежде на скорое отчуждение всей земли бесплатно) и принятие дарового нищенского надела (1/4 высшего надела) (ст. 123 Положения), что приводило к тому, что вся оставшаяся земля доставалась помещику.

Вторая причина малоземелья связана с общинным землевладением. Русская крестьянская община в XIX в. - это уравнительная община. В пореформенной России община сохранилась, потому что 2019. T. 20, № 4. C. 601-624 
выполняла ряд важных социальных функций, она стала единицей государственного управления, а также органом хозяйственного управления, она стала удобна для государства. Но в сложившихся условиях сельскохозяйственного кризиса община усугубляла ситуацию. Проблемой общины было отсутствие предприимчивости у отдельных крестьян, что очень тормозило развитие хозяйства. Крестьянин, затрачивая много труда, получал ничтожный результат, стимул к работе пропадал, так как благосостояние крестьянина совершенно не увеличивалось. Вдобавок ко всему население общины постоянно росло, а земельные угодья, находящиеся в ее распоряжении, оставались неизменными, соответственно, рано или поздно наступал момент, когда на каждого члена общины приходилось недостаточное количество земли. Общинное землевладение представляет некоторые выгоды только во времена земельного изобилия и в период натурального хозяйства. Когда же население увеличивается настолько, что при равномерном распределении земли все земледельцы получают недостаточные участки, тогда общинное землевладение оказывается явно несостоятельным [16, с. 12]. По мнению А.Е. Воскресенского, необходимо было уничтожить право на землю, основанное на принадлежности к общине, и тогда крестьянские семьи, столкнувшиеся с невозможностью прокормиться, обращались бы к неземледельческим промыслам. Тем самым формировался бы новый слой общества и уменьшалось дробление земельных угодий. Указанную точку зрения разделяли многие управленцы, считая, что прививание потомкам малоземельных крестьян стремления к личному труду в будущем вырастит рабочий класс для предпринимателей. Более либеральные мнения содержали идею о свободном выходе из общины с получением платы за долю своей земли, либо с возможностью продажи своего участка земли. Так или иначе, 
но община уравнивала всех в малоземелье и приводила к бедности всех в равной степени.

Третьей основной причиной малоземелья является естественный прирост населения. С 1860 г. по 1900 г. население деревни возросло на 72 \% (по материалам «Комиссии об оскудении центра») [6, с. 20]. Докладчик думской земельной комиссии С.И. Шидловский указывал, что ввиду ограниченного пространства земли и постоянного роста населения должно неизбежно наступить малоземелье, должен рано или поздно почувствоваться недостаток земли. С этим фактором, наименее поддающимся контролю, ничего нельзя было поделать, но он же по необходимости вынуждает крестьян обращать внимание на улучшение земельной культуры [17, с. 235]. Действительно, земледелие в России всегда было экстенсивным, техника обработки земли была простой и никак не способствовала повышению качества земли. Так как земли было много, крестьянин всегда мог перейти на другой участок. Но в условиях малоземелья такая роскошь была невозможна, поэтому возрастала актуальность интенсивного земледелия. В трудах сельскохозяйственных комитетов даже само малоземелье уходит на второй план, в то время как главной причиной сельскохозяйственных затруднений объявлялась отсталость хозяйственных приемов обработки земли [18, с. 381]. Желание выставить отсталость крестьянских методов первопричиной упадка производительности сельского хозяйства было способом избежать конфликта с крупными земельными собственниками, и решение, предлагаемое комитетами, заключалось именно в развитии сельскохозяйственной техники. Однако это действие целесообразно только как дополнительная мера при улучшении положения аграрной сферы. Основной же проблемой представляется все же малоземелье.

Покупательная способность крестьянина полностью обуславливается прибылью от земледельческой 2019. T. 20, № 4. C. 601-624 
деятельности, которая в свою очередь зависит от размеров и интенсивности земледелия. Развитие торгово-промышленной сферы основывается на сельском хозяйстве, так как из всех промыслов земледелие и животноводство является первоначальным. Сельское хозяйство удовлетворяет самые первичные потребности человека в еде и одежде. При натуральном хозяйстве человек полностью мог обеспечить себя, свой быт, свое жилище, и никакая промышленность была ему не нужна. С развитием неземледельческих сфер производства постепенно возрастает спрос на сельскохозяйственную продукцию со стороны промышленных работников. Но в сложившихся условиях малоземелья весь этот процесс замедлялся из-за застоя и малой производительности аграрного сектора. Нужда в земле заставляла крестьян сокращать пастбища и луга в пользу увеличения доли пашни [19, с. 83-84, 92], а это отрицательно сказывалось на животноводстве. В конечном итоге и промышленность, и торговля, и кредит, и транспорт, и страхование развивается лишь настолько, насколько это допускает покупательная способность земледельческого населения [16, с 158]. И в условиях России массовое малоземелье задерживало экономическое развитие, поэтому уровень развития промышленности искусственно поддерживался государством как раз за счет аграрного сектора страны (через перераспределение средств выкупных платежей в пользу промышленности). Эта поддержка была крайне необходима. В 1900 г. народный доход в 50 губерниях Европейской России составлял 6,125 млрд р. (от сельского хозяйства - 2,738 млрд р., от добывающей и обрабатывающей промышленности - 1,494 млрд р.). Годовой доход на душу населения равнялся 63 р. (1518 коп. в день) [13, с. 206]. К 1902 г. произошло удешевление промышленных товаров, Министерство финансов считало, что это будет усиливать спрос и вызовет новый промышленный подъем. Но народ нуждался 
прежде всего в дешевом хлебе и только после в дешевых предметах промышленности. Таким образом, упадок в народном хозяйстве, определявшийся покупательной способностью населения, не способствовал развитию промышленно-производительных сил страны. Несостоятельность политики искусственной поддержки промышленности показывала, что в первую очередь необходимо было обеспечивать нужды сельского хозяйства, мелкой сельскохозяйственной промышленности и мелочной торговли [20, с. 11].

Безусловно, перспектива решения проблемы малоземелья могла быть связана только с реформированием земледельческого быта крестьян. С теоретической точки зрения вопрос этот имел много путей решения, и ученые-экономисты того времени указывали их. Вот, к примеру, что предлагал профессор Московского университета А.А. Мануйлов: «1) признание казенных и удельных земель государственным фондом, не отчуждаемым и подлежащим эксплуатации путем сдачи в пользование крестьянам, 2) выкуп в собственность государства части владельческих земель в целях дополнительного наделения на началах пользования малоземельных и безземельных крестьян, и 3) широкое регулирование аренд» [6, с. 5].

Одним из решений проблемы малоземелья, доступных для крестьян, была аренда дополнительных наделов (а иногда и вынужденный нелегальный захват частновладельческих земель [там же, с. 35]). При аренде дополнительных наделов с одной стороны решался вопрос о размере земельного участка, с другой создавались новые препятствия к развитию сельского хозяйства. Помещичья земля сдавалась крестьянам за отработки на их пашне крестьянским инвентарем и делением полученного результата в виде продуктов пополам. В основе этой системы лежал дореформенный механизм эксплуатации крестьян, то есть неформально мы наблюдаем крепостной строй - в виде 2019. T. 20, № 4. C. 601-624 
отработок и натуральных аренд. Крупные земельные собственники с каждым годом поднимали цену аренды и понимали, что большая доходность с земли будет от сдачи за деньги, что ставило крестьян в более тяжелое положение. Естественно, что вынужденные, вследствие недостаточности собственной земли, арендовать угодья помещиков, крестьяне не могли не подчиняться условиям, которые помещики им диктовали [17, с. 242]. Бывали случаи, когда не все крестьянские дворы, получившие надел, непосредственно пользовались этой землей. Те дворы, которые сдавались или запускались, назывались бесхозяйными. Для 140 уездов Европейской России по земским переписям среднее относительное количество бесхозяйных дворов составляло 10 \% от общего числа надельных дворов. Такие домохозяйства земледелием не занимались и всю свою землю сдавали в аренду. Обеспеченные хозяева этих земель открывали промысловые заведения, а те, кто беднее, нанимались в работники либо уходили в другие местности. Близость различного рода промышленных и торговых центров приводила к увеличению бесхозяйных дворов. Так или иначе, при прочих равных условиях, чем выше была хозяйственная обеспеченность какой-нибудь группы крестьянского населения, тем меньше в этой группе был процент бесхозяйных дворов [21, с. 82]. Со стороны государства по отношению к аренде не было установлено никакого регулирования и контроля. Вопрос оставался открытым к обсуждению в правительстве. Внесенный в Государственную Думу второго созыва «Проект главных оснований закона о земельном обеспечении земледельческого населения» (1907 г.) предлагал решение: отчуждать из частной собственности земли, сдаваемые трудовому земледельческому населению. Даже консерваторы выступали за регулирование аренды. Планировать переход к интенсивному земледелию, к повышению продуктивности земли, к улучшениям 2019 , vol. 20 , no. 4 , pp. $601-624$ 
в сельском хозяйстве, без урегулирования вопроса об аренде земли было невозможно. Любые небольшие выгоды крестьян в будущем уходили бы на выплату постоянно дорожающей аренды. Необходим был контроль над сроком найма (от краткосрочного нужно было стремиться к более длительному), над улучшением качества земли, над арендной платой.

А.А. Мануйлов считал, что исправление сложившегося аграрного строя необходимо предоставить землевладельческому классу (т.е. улучшение материального благосостояния крестьянского населения должно производиться за счет помещиков). Известный же экономист Пешехонов А.В. шел дальше и в своих трудах рассматривал идею национализации земли. В сборнике «Земельные нужды деревни и основные задачи агарной реформы» он обосновывает план национализации как необходимого аграрного преобразования. А.В. Пешехонов считал, что для усиления земледельческих хозяйств за счет дополнительного наделения землей важно выбрать институт поземельной собственности, который полностью соответствовал бы интересам сельскохозяйственных трудящихся и всего общества [7, с. 150]. Если в Западной Европе развивается «личная собственность» на землю, то для России она не подходит в силу массовой бедности крестьян, этот путь привел бы к сплошному обезземеливанию. Со временем весь безземельный пролетариат отправился бы в город, промышленность не обеспечила бы сразу всех работой, часть населения отправилась бы обратно в деревни и работать пришлось бы на полностью арендованных землях. Такой ход событий вернул бы прежние условия взаимодействия крестьянина и землевладельца, то есть эксплуатацию земледельцев. Если пойти по пути дополнительного наделения крестьян землей для перехода их на интенсивное развитие хозяйства, то, как считал А.В. Пешехонов, это реализуемо в теории. Но по итогу неизвестно, 2019. T. 20, № 4. C. 601-624 
за кем осталась бы закреплена земля и на какое время указанная мера устранила бы малоземелье. Важно было улучшить само экономическое и культурное положение крестьянства. Отчуждать землю у одного собственника, чтобы передать в собственность другому, - замкнутый круг. А вот освобождая землю от собственника мы освобождаем и саму личность. Однако сложившийся институт государственной собственности требует по мнению Пешехонова радикальной модернизации: права на эти земли должны перейти трудящимся, заведывание землями - особому выборному органу. Сам проект национализации земли выглядел масштабным, даже возможно непосильным, однако по статистическим данным крестьянское население выплачивало за аренду дополнительной земли гораздо большее количество средств, нежели то, которое потребовалось бы для национализации. Мнение о том, что земля не должна быть частной собственностью, а должна принадлежать всему народу, всему государству, нации, постепенно становится популярным в науке. Весь народ, улучшая обработку земли, проводя железные дороги, устраивая рынки сбыта повышает ценность земли и ее доходность. Эти выгоды не должны попадать в карманы отдельных лиц [22, с. 6-7]. Существует высокая вероятность того, что путем национализации возможно разрешить проблемы, связанные с обезземеливанием крестьян.

Другой аспект реформирования крестьянского быта, рассматривавшийся в трудах ученых-экономистов на рубеже XIX-XX вв. в контексте национализации земли, - установление нормы надела: низшей («потребительной») и высшей («трудовой»). Нормированные наделы должны были находиться вблизи усадеб, что гораздо эффективнее с точки зрения траты времени. Государственная земля предоставлялась бы крестьянам в личное пользование. Это позволило бы реализоваться крестьянам в своем труде, увеличи- 
вать урожайность, привлекать новых работников. Подобную концепцию рассматривал экономист А.С. Посников. По его мнению, трудовая норма надела - это некий предел, идеал, к которому стоит стремиться, но при этом такой надел - не обязательный. Минимальная норма должна была соответствовать высшей норме надела по Манифесту 1861 г. Везде, где будет возможно, необходимо наделять крестьян сверх низшей нормы, при условии обработки земли исключительно собственными силами. Установление максимальной нормы было необходимо для того, чтобы в одних руках не сосредотачивалось большое количество земельных угодий. Вряд ли бы можно было ожидать повсеместного стремления к высшей норме надела, однако с точностью сохранилась бы низшая норма, и крестьяне смогли бы обеспечивать свой быт. Несмотря на приведенные А.С. Посниковым расчеты, его оппоненты считали, что земли не хватит для наделения всех даже минимальной нормой. Но А.С. Посников, отстаивая свои расчеты и ориентируясь также на труды А.А. Чупрова и А.А. Мануйлова, утверждал, что земли более чем хватит [17, с. 245-246].

На практике правительство применяло ряд мер для решения проблемы малоземелья крестьян. Несколько организаций занимались сбором материалов, анализом и выработкой практических решений. К таковым относились Комиссия по решению сельскохозяйственных трудностей, Особая сельскохозяйственная комиссия, возглавляемая А. Нарышкиным, Министерство земледелия и государственных имуществ, Комиссия об оскудении Центра, Редакционная комиссия под началом А.С. Сташинского, Особое совещание о нуждах сельскохозяйственной промышленности во главе с С.Ю. Витте. После создания последней в 1902 г., обрадовавшись возможности открыто высказываться о наболевших нуждах русского сельского хозяйства, люди разных профессий и самых различных 2019. T. 20, № 4. C. 601-624 
социальных положений взялись за перо. Их искренние мысли, подсказанные желанием пользы и добра родине, поступали в Особое совещание и его местные комитеты в форме докладов, записок, брошюр, мнений [23, с. 5]. Но единого мнения выработано так и не было. Государством решался вопрос исключительно двумя способами: способствование приобретения земли крестьянами через Крестьянский банк либо переселение на свободные земли. Сложившаяся система купли-продажи земли через банк имела свою особенность: при таких операциях земля доставалась экономически крепким крестьянам и не доставалась тем, кто особо в ней нуждался, так как покупать ее могли только платежеспособные люди. Официальная миссия Крестьянского банка заключалась именно в помощи приобретения земли безземельными и малоземельными крестьянами, но коммерческие интересы банка способствовали другому [24, с. 6]. Складывалась ситуация, при которой распределение земли осуществлялось не по хозяйственным потребностям, а исключительно между теми, кто обладал способностью платить за нее. Другой стороной этого процесса было сильное дробление частновладельческих земель, что не особо содействовало повышению производства сельскохозяйственной продукции, ведь сохранение крупного и среднего землевладения для страны имело стратегическое значение, - именно такой вид хозяйства в условиях России способствовал росту рынка сельскохозяйственных продуктов и полностью удовлетворял продовольственные потребности населения. Также это имело огромное значение для торгового баланса страны. Чтобы при громадной внешней задолженности золото не ушло за границу, вывоз ежегодно должен был превышать ввоз на большие суммы. На вывоз большого числа фабричных и заводских изделий рассчитывать не приходилось, зато можно было вывозить в большом количестве продукты сельско- 
го хозяйства, а избыток их по преимуществу давало крупное и среднее землевладение. Содействуя раздроблению частновладельческих земель и расширению площади мелкого потребительного хозяйства, аграрная политика правительства затрудняла поддержание активного торгового баланса и устойчивости золотой валюты [16, с. 109-110].

Важной чертой политики государства по преодолению крестьянского малоземелья была поддержка начавшегося процесса переселения крестьян за Урал, на Кавказ и на юго-восток Европейской России. Пишущая общественность полностью поддерживала переселение крестьян на казенные земли Сибири. Деятели различных комитетов считали это выгодным для страны: во-первых, это сулило максимально эффективное освоение бездоходных государственных земель; во-вторых, это позволяло сохранить за крупными и средними землевладельцами их земли. Действительно, складывавшиеся перспективы казались найденным решением проблемы крестьянского малоземелья, ведь оставшиеся в своих селениях крестьяне получали земли переселившихся. Однако, все же были и опасения, связанные с отсутствием планирования в этом вопросе: было непонятно, как количество оставшихся работников будет сопоставляться с наличной землей, вызывала беспокойство у некоторых потеря арендодателями доходов, непонятно было, какие опасности несет само стихийное переселение. Могло быть и так, что малообразованный народ, оказавшись на новом месте без государственной поддержки, не сможет самостоятельно окультуривать землю. Государственная поддержка была переселенцам необходима, но, чтобы «сносно» размещать до миллиона крестьян ежегодно в Сибири, нужно было бы им выдать «вспомоществования» около 200 млн р. Реальная помощь переселенцам от казны была ничтожна, а в Сибири переселенцы по умолчанию считались нищими [25, с. 2-3]. Конеч2019. T. 20, № 4. C. 601-624 
но, переселение имело свои важные последствия для развития аграрной сферы и крестьянского быта, но оно не решало аграрного вопроса. Крестьянам нужно было не переселение, а расселение и создание соответствующих условий для плодотворной сельскохозяйственной работы.

Положение дел в крестьянском хозяйстве в России всегда играло важную роль, и должно было быть на рубеже XIX-XX вв. в условиях прогрессирующего малоземелья важнейшим направлением работы правительства, поскольку платежи крестьян составляли половину государственного бюджета, а успехи хозяйств помещиков также зависели от крестьян. Целью реформы 1861 г. было полное освобождение крестьянина от власти помещика в личном и хозяйственном отношениях, но в итоге к началу XX в. «освобожденный крестьянин» становился подневольным батраком и арендатором. Только после того, как крестьянин получил бы достаточное количество земельных угодий, можно было бы констатировать полное завершение крепостных отношений. Потеря помещиками почти бесплатной рабочей силы способствовала переходу их на капиталистические начала. Чтобы развить аграрный капитализм, требовался переход от натурального производства к товарному. Крестьянское хозяйство жило в соответствие с феодальными принципами: часть продукта потреблялось семьей, остальное отправлялось на продажу. Капитализм же подразумевает, что производимые продукты предназначались для продажи, а покупка нужных товаров осуществлялась на выручку от продажи. В этом заключалось принципиальное отличие крестьянина от фермера. В будущем переход от производства различных продуктов к производству одного товара обусловил бы региональную специализацию. Например, на севере выгодно было заниматься травосеянием и сбытом сена, но не хлебопашеством. Деление страны на климатические 
зоны и исследование особенностей каждой имело важное значение в этом смысле, так как недооценка разнообразия природно-климатических условий, а также игнорирование исторического опыта, накопленного населением, неизбежно оказало бы негативное влияние на производительность аграрной сферы страны $[26$, с. 5]. Далее, для того, чтобы обеспечить взаимодействие между специализирующимися областями, необходимым стало бы развитие дорог и прочих коммуникаций. Это привело бы к экономическому подъему во многих отраслях, но самое главное - в аграрно-промышленной сфере. С устранением малоземелья крестьянское хозяйство могло бы встать на путь экономической свободы и безграничного совершенствования. Но развитие капитализма в деревне сдерживалось пережитками старого порядка, что препятствовало внедрению новаций. Важно, что общественная мысль России стремилась соединить науку и аграрную практику, но никакие попытки «улучшения быта» крестьян без решения проблемы малоземелья не могли быть успешными. С другой стороны, расширение крестьянских наделов имело бы смысл при условии одновременного повышения образовательного уровня крестьян и распространения интенсивных методов земледелия.

\section{Список использованной литературы}

1. Булгаков С.Н. Капитализм и земледелие : в 2 т. / С.Н. Булгаков. - Санкт-Петербург : тип. и литогр. В.А. Тиханова, 1900. - 2 т.

2. Чаянов А.В. Организация крестьянского хозяйства / А.В. Чаянов. - Москва : Академический Проект, 2015. - 362 с.

3. Кондратьев Н.Д. Аграрный вопрос о земле и земельных порядках / Н.Д. Кондратьев. - Москва : Универс. б-ка, 1917. - 64 с.

4. Ходский Л.В. Земля и земледелец: Экономическое и статистическое исследование Л.В. Ходского, доцента политической экономии и статистики в С.-Петербургском лесном институте : в 2 т. / Л.В. Ходский. - Санкт-Петербург : Тип. М.М. Стасюлевича, 1891. - 2 т. 
5. Кауфман А.А. Что говорят цифры о земельном вопросе / А.А. Кауфман. - Петроград : Партия Народной свободы, 1917. - $16 \mathrm{c}$.

6. Мануйлов А.А. Поземельный вопрос в России : Малоземелье, дополнительный надел и аренда / А.А. Мануилов. Москва, 1905. - 106 с.

7. Пешехонов А.В. Земельные нужды деревни и основные задачи аграрной реформы / А.В. Пешехонов. - Санкт-Петербург : ред. журн. «Рус. богатство», 1905. - 158 с.

8. Маслов П.П. Аграрный вопрос в России : Т. 1-2 / П.П. Маслов. - Санкт-Петербург : тип. т-ва «Обществ. польза», 1905-1908. - 2 т.

9. Бар Ф.Ф. Общинное землевладение, малоземелье, переселение и земледельческий, экономический, торговый кризис в России / Ф.Ф. Бар. - Санкт-Петербург : тип. В. Киршбаума, 1886. - 52 с.

10. Демчинский Н.А. Решение агарного вопроса / Н.А. Демчинский. - Санкт-Петербург : тип. А.С. Суворина, 1907. - 93 с.

11. Исаев А.А. Переселение в русском народном хозяйстве / А.А. Исаев. - Санкт-Петербург : А.Ф. Цинзерлинг, 1891. - 192 с.

12. Лохтин П.М. К вопросу о реформе сельского быта крестьян / П.М. Лохтин. - Москва : типо-литогр. А.В. Васильева и Ко, 1902. - 156 с.

13. Рубакин Н.А. Россия в цифрах. Страна. Народ. Сословия. Классы / Н.А. Рубакин. - Санкт-Петербург : Вестник Знания, 1912. - 216 с.

14. Соковнин П.Н. Крестьянское малоземелье и наличный запас земель / П.Н. Соковнин. - Санкт-Петербург : тип. В.Ф. Киршбаума, 1905. - 33 с.

15. Янсон Ю.Э. Опыт статистического исследования о крестьянских наделах и платежах / Ю.Э. Янсон. - Санкт-Петербург : Тип. М.М. Стасюлевича, 1877. - 186 с.

16. Воскресенский А.Е. Общинное землевладение и крестьянское малоземелье / А.Е. Воскресенский. - Санкт-Петербург : Лит. и наука, 1903. - 207 с.

17. Посников А.С. Аграрный вопрос в Третьей Думе: Малоземелье и дополнительное наделение / А.С. Посников // Вестник Европы. - 1909. - Т. 1. - С. 233-248.

18. Фигуровская Н.К. Меры российского правительства по развитию сельского хозяйства (по документам Министерства финансов России конца XIX - начала XX вв.) / Н.К. Фигуровская. И.А. Благих // Проблемы современной экономики. - 2012. - № 3 (43). - С. 381-385. 
19. Петров В.И. Население Среднего Поволжья и Южного Приуралья во второй половине XIX века (Казанская, Симбирская, Самарская, Оренбургская, Уральская губернии) / В.И. Петров. - Оренбург : Изд-во Оренбург. гос. ун-та, 2005. - 267 c.

20. Бадмаев П.А. Десятый доклад министра финансов С.Ю. Витте и взгляды теоретиков и практиков по вопросам сельскохозяйственной жизни в России / П.А. Бадмаев. - Санкт-Петербург : паровая скоропеч. Г.П. Пожарова, 1902. - 38 с.

21. Сельскохозяйственная статистика Европейской России / сост. А. Фортунатов. - Москва : типо-литогр. т-ва И.Н. Кушнерев и Ко, 1893. - 246 с.

22. Лебедев А.И. Крестьянское малоземелье и национализация земли / А.И. Лебедев. - Нижний Новгород : А.И. Лебедев, 1917. - 16 с.

23. Лебедев С.С. Необходимые аграрные реформы в России / С.С. Лебедев. - Москва : типо-литогр. И.Н. Кушнерев и Ко, 1903. - 37 c.

24. Скалон В.Ю. Крестьянский поземельный банк и малоземелье / В.Ю. Скалон. - Москва : Новое слово, 1907. - 16 с.

25. Михайловский Э.И. Решение аграрного вопроса в России / Э.И. Михайловский. - Санкт-Петербург : тип. Тренке и Фюсно, 1906. - 10 с.

26. Майдачевский Д.Я. История как хранилище опыта, или обращение к истокам местной народной агротехники / Д.Я. Майдачевский // Иркутский историко-экономический ежегодник. 2012. - Иркутск, 2012. - С. 5-15.

\section{References}

1. Bulgakov S.N. Kapitalizm i zemledelie. [Capitalism and farming]. Saint-Petersburg, V.A. Tikhanov Publ., 1900. 2 vol.

2. Chayanov A.V. Organizatsiya krest' yanskogo khozyaistva. [Organization of peasant farming]. Moscow, Akademicheskii Proekt Publ., 2015. 362 p.

3. Kondratev N.D. Agrarnyi vopros o zemle i zemel'nykh poryad$k a k h$. [Agrarian question of land and land regulations]. Moscow, Universitetskaya biblioteka Publ., 1917. 64 p.

4. Khodskii L.V. Zemlya i zemledelets: Ekonomicheskoe i statisticheskoe issledovanie L.V. Khodskogo, dotsenta politicheskoi ekonomii i statistiki $v$ S.-Peterburgskom lesnom institute. [Land and the Farmer: Economic and Statistical Research by L.V. Khodsky, assistant professor of political economy and statistics at St. Petersburg Forest Institute]. Saint-Petersburg, M.M. Stasyulevich Publ., 1891. 2 vol. 
5. Kaufman A.A. Chto govoryat tsifry o zemel'nom voprose. [What do the numbers say about the agrarian issue]. Petrograd, Partiya Narodnoi svobody Publ., 1917. 16 p.

6. Manuilov A.A. Pozemel'nyi vopros v Rossii : Malozemel'e, dopolnitel'nyi nadel $i$ arenda. [Land issue in Russia: land shortages, additional allotment, and lease]. Moscow, 1905. 106 p.

7. Peshekhonov A.V. Zemel'nye nuzhdy derevni i osnovnye zadachi agrarnoi reformy. [Land needs of the village and main objectives of the agrarian reform]. Saint-Petersburg, Russkoe bogatstvo Publ., 1905. $158 \mathrm{p}$.

8. Maslov P.P. Agrarnyi vopros $v$ Rossii. [Agrarian issue in Russia]. Saint-Petersburg, Obshchestvennaya pol'za Publ., 1905-1908. 2 vol.

9. Bar F.F. Obshchinnoe zemlevladenie, malozemel'e, pereselenie $i$ zemledel'cheskii, ekonomicheskii, torgovyi krizis v Rossii. [Community farming, land shortage, resettlement, agricultural, economic, and trade crisis in Russia]. Saint-Petersburg, V. Kirshbaum Publ., 1886. $52 \mathrm{p}$.

10. Demchinskii N.A. Reshenie agarnogo voprosa. [Solution of the agrarian issue]. Saint-Petersburg, A.S. Suvorin Publ., 1907. $93 \mathrm{p}$.

11. Isaev A.A. Pereselenie v russkom narodnom khozyaistve. [Resettlement in the Russian national economy]. Saint-Petersburg, A.F. Tsinzerling Publ., 1891. 192 p.

12. Lokhtin P.M. K voprosu o reforme sel'skogo byta krest'yan. [On the issue of the reform of rural life of peasants]. Moscow, A.V. Vasil'ev i Ko Publ., 1902. 156 p.

13. Rubakin N.A. Rossiya v tsifrakh. Strana. Narod. Sosloviya. Klassy. [Russia in numbers. Country. People. Estates. Classes]. Saint-Petersburg, Vestnik Znaniya Publ., 1912. 216 p.

14. Sokovnin P.N. Krest'yanskoe malozemel'e i nalichnyi zapas zemel' [Peasant land shortages and land supply]. Saint-Petersburg, V.F. Kirshbaum Publ., 1905. 33 p.

15. Yanson Yu.E. Opyt statisticheskogo issledovaniya o krest'yanskikh nadelakh $i$ platezhakh. [The experience of statistical research on peasant allotments and payments]. Saint-Petersburg, M.M. Stasyulevich Publ., 1877. 186 p.

16. Voskresenskii A.E. Obshchinnoe zemlevladenie i krest'yanskoe malozemel'e. [Community farming and peasant land shortages]. Saint-Petersburg, Literatura i nauka Publ., 1903. 207 p.

17. Posnikov A.S. Agrarian issue in the Third Duma: Land shortages and additional land allotment. Vestnik Evropy $=$ Herald of Europe, 1909, vol. 1, pp. 233-248. (In Russian). 
18. Figurovskaya N.K., Blagikh I.A. Measures Taken by the Russian Government for Agricultural Development (Based on the Documents of the Russian Ministry of Finances, end XIX - beginning XX c.). Problemy sovremennoi ekonomiki $=$ Problems of Modern Economics, 2012, no. 3 (43), pp. 381-385. (In Russian).

19. Petrov V.I. Naselenie Srednego Povolzh'ya i Yuzhnogo Priural'ya vo vtoroi polovine KhIKh veka (Kazanskaya, Simbirskaya, Samarskaya, Orenburgskaya, Ural'skaya gubernii). [The population of the Middle Volga and Southern Urals in the second half of the XIX century (Kazan, Simbirsk, Samara, Orenburg, Ural provinces]. Orenburg State University Publ., 2005. 267 p.

20. Badmaev P.A. Desyatyi doklad ministra finansov S.Yu. Vitte $i$ vzglyady teoretikov i praktikov po voprosam sel'skokhozyaistvennoi zhizni v Rossii. [Tenth report of the Minister of Finance S.Yu. Witte and the views of theorists and practitioners on agricultural life in Russia]. Saint-Petersburg, G.P. Pozharov Publ., 1902. 38 p.

21. Fortunatov A. (ed.). Sel'skokhozyaistvennaya statistika Evropeiskoi Rossii. [Agricultural statistics of European Russia]. Moscow, I.N. Kushnerev i Ko Publ., 1893. 246 p.

22. Lebedev A.I. Krest'yanskoe malozemel'e $i$ natsionalizatsiya zemli. [Peasant land shortage and nationalization of the land]. Nizhny Novgorod, A.I. Lebedev Publ., 1917. 16 p.

23. Lebedev S.S. Neobkhodimye agrarnye reformy $v$ Rossii. [Necessary agrarian reforms in Russia]. Moscow, I.N. Kushnerev i Ko Publ., 1903. 37 p.

24. Skalon V.Yu. Krest'yanskii pozemel'nyi bank i malozemel'e. [Peasant land bank and land shortages]. Moscow, Novoe slovo Publ., 1907. 16 p.

25. Mikhailovskii E.I. Reshenie agrarnogo voprosa v Rossii. [The solution of the agrarian question in Russia]. Saint-Petersburg, Trenke i Fyusno Publ., 1906. 10 p.

26. Maidachevskii D.Ya. History as a repository of experience, or an appeal to the origins of local folk agricultural technology. Irkutskii istoriko-ekonomicheskii ezhegodnik: 2012 [Irkutsk Historical and Economic Yearbook: 2012]. Irkutsk, 2012, pp. 5-15. (In Russian).

\section{Информация об авторе}

Лапыикая Марина Андреевна - аспирант, экономический факультет, кафедра истории экономики и экономической мысли Санкт-Петербургского государственного университета, 191123, г. Санкт-Петербург, ул. Чайковского, 62, e-mail: Lama93@yandex.ru. SPIN-код: 4335-2077; AuthorID: 1040033. 


\section{Author}

Marina A. Lapytskaya - Postgraduate Student of the Economics Department, Saint Petersburg State University, 62 Chaykovskiy street, St. Petersburg, 191123, e-mail: Lama93@ yandex.ru. SPIN-код: 4335-2077; AuthorID: 1040033.

\section{Для цитирования}

Лапыцкая М.А. Преобразования в аграрной сфере как способ разрешения проблем крестьянского малоземелья в России (по материалам исследований аграрных реформ в России второй половины XIX - начала XX вв.) / М.А. Лапыцкая. - DOI: 10.17150/2308-2488.2019.20(4).601-624 // Историко-экономические исследования. - 2019. - Т. 20, № 4. - C. 601-624.

\section{For Citation}

Lapytskaya M.A. Transformations in the Agrarian Sector as a Method of Problem Resolution of the Peasant Land Shortages in Russia (Based on the Research on Agrarian Reforms in Russia in Second Half of XIX - Beginning of the XX Centuries). Istoriko-ekonomicheskie issledovaniya $=$ Journal of Economic History \& History of Economics, 2019, vol. 20, no. 4, pp. 601-624. DOI: 10.17150/2308-2488.2019.20(4).601-624. (In Russian). 